\title{
Grounded theory research on the factors that lead to doctor moral hazard
}

\section{Pesquisa sobre fatores que levam ao risco moral médico com base na teoria fundamentada}

\author{
Yaohui Wang ${ }^{a, b}$ \\ (D) https://orcid.org/0000-0002-5998-2809 \\ E-mail: wangyaohuiळenzemed.com \\ Jiankun Dong ${ }^{b}$ \\ (D) https://orcid.org/0000-0001-7855-5477 \\ E-mail: soramoreळzju.edu.cn

\section{Xifeng Wang ${ }^{c}$} \\ (D) https://orcid.org/0000-0002-6580-9359 \\ E-mail: wangxifengळenzemed.com

\section{Quanlong Liu $^{\mathrm{a}}$} \\ (D) https://orcid.org/0000-0002-8789-7660 \\ E-mail: qll2016œcumt.edu.cn

\section{Xinchun $\mathbf{L i}^{\mathrm{a}}$} \\ (iD) https://orcid.org/0000-0003-4595-5268 \\ E-mail: ezwyhळ163.com \\ ${ }^{a}$ China University of Mining $\varepsilon$ Technology. School of Economic \\ and Management. Xuzhou, China. \\ ${ }^{b}$ Zhejiang University. Health Industry Innovation Research \\ Center. Hangzhou, China. \\ 'Taizhou Hospital of Zhejiang Province. Taizhou, China.
}

\section{Abstract}

Moral hazard clearly exists among doctors, and it has a dramatic impact on doctor-patient relationships, medical costs and medical risks. This study explored the factors that lead to doctor moral hazard, as well as the interrelationships and internal regularity of these factors. This study takes doctor moral hazard as the research content and the inducing factors as the core theme, conducting grounded theory research on the causes of doctor moral hazard. Scientific understanding of doctor behavior would facilitate the prevention and control of doctor moral hazard behavior. This study used the principles and methodology of Glaser and Strauss's grounded theory. Theoretical and snowball samplings were used to identify 24 subjects. Semi-structured indepth interviews were conducted with each subject. Themes were identified through substantial (open) coding and theoretical coding. The factors that lead to doctor moral hazard were categorized into five dimensions, i.e. motivation, opportunity, selfrationalization, exposure and punishment. These five factors influence each other, forming the inducing mechanism of doctor moral hazard. This will provide useful theoretical support and method guidance for the follow-up prevention and control of moral hazard for doctors.

Keywords: Doctor Moral Hazard; Grounded Theory; Semi-Structured In-Depth Interviews.

\section{Correspondence}

Quanlong Liu

China University of Mining $\varepsilon$ Technology. School of Economics and Management. B504, University RD. I, Xuzhou, Jiangsu Province, P. R. China. 


\section{Resumo}

O risco moral existe claramente entre os médicos e tem um impacto dramático nas relações médicopaciente, custos e riscos médicos. Este estudo explorou os fatores que levam ao risco moral por parte do médico, bem como as inter-relações e a regularidade interna desses fatores. Este estudo considera o risco moral do médico como o conteúdo da pesquisa e os fatores indutores como o tema central, conduzindo pesquisas de teoria fundamentada sobre as causas do risco moral do médico. A compreensão científica do comportamento do médico facilitaria a prevenção e o controle do comportamento de risco moral do médico. Este estudo usou os princípios e a metodologia da teoria fundamentada de Glaser e Strauss. Amostragens teóricas e em snowball foram utilizadas para identificar 24 sujeitos. Entrevistas semiestruturadas em profundidade foram realizadas com cada sujeito. Os temas foram identificados por meio de codificação substancial (aberta) e codificação teórica. Os fatores que levam ao risco moral do médico foram categorizados em cinco dimensões: motivação, oportunidade, autorracionalização, exposição e punição. Esses cinco fatores influenciam-se mutuamente, formando o mecanismo indutor do risco moral médico. Isso fornecerá suporte teórico útil e orientação metodológica para o acompanhamento da prevenção e controle de risco moral para os médicos.

Palavras-chave: Risco Moral de Médicos; Teoria Fundamentada; Entrevistas Semiestruturadas em Profundidade.

\section{Introduction}

Doctor moral hazard is inevitable in healthcare services due to information asymmetry. In general, moral hazard includes both the moral hazards of the demander and of the supplier (Einav; Finkelstein, 2018). The central agent in supplier moral hazard is the doctor. Doctor moral hazard has led to rapid growth in medical costs in various countries. For example, healthcare expenditure in the United States rose from 26.9 billion USD in 1960 to 1,149.1 billion USD in 1988, accounting for 14\% of GDP (Levit et al., 2000). On 23 March 2010, President Barack Obama signed the Patient Protection and Affordable Care Act to reduce the costs of healthcare for both individuals and the government (Mendoza et al., 2016). Many believe doctor moral hazard is caused by information asymmetry, opportunity and self-rationalization (Eliason; Johansson; Nilsson, 2018). Arrow suggested that the concept of moral hazard could be applied to healthcare in 1963. He observed that the differences in patient health could be accurately assessed by doctors, due to their professional training, and that doctors were also capable of creating demand of medical services (Arrow, 1963). For example, a doctor could ask a patient to undergo expensive tests. In medical insurance, the moral hazard of healthcare providers is the opportunistic behavior driven by doctors' economic interests, during which they take advantage of the information they possess, thus increasing medical costs.

The theory of information economics indicates that moral hazard is an opportunistic behavior. Doctor moral hazard refers to opportunistic behavior that maximizes the interests of doctors while it might damage interests of patients. Some researchers also contend that doctors' moral hazard refers to doctors' induced demand. A study has shown that moral hazard in healthcare is concentrated on medication, hospitalization, and patient examination (Evans, 1974). Evans found that doctor moral hazard was manifested in examinations and drug administration, such as unnecessary or expensive examination, and expensive or overused drug administration. A subsequent study showed that overcharging and receiving monetary gifts, which are not treatmentrelated activities, were part of doctor moral hazard (Doran; Robertson; Henry, 2004). However, doctor 
moral hazard is primarily explained by information asymmetry, opportunity, and self-rationalization, and it directly leads to increased medical costs.

In April 2009, China initiated the New Medical Reform and introduced a series of measures that were intended to rebuild the healthcare system and emphasize the government's leadership of public welfare. The control of medical expenditure and the supervision of medical activity have gradually become the focus of medical reform. Accordingly, the U.S. government proposed healthcare reform plans in 2010 to resolve the problems of ever-increasing medical costs and medical risks (Cheraghi et al., 2018), during which doctor moral hazard objectively exists and have dramatic impacts. To achieve the goal of medical reform, every country must deeply scrutinize and figure out the factors that influence doctor moral hazard and its mechanism, which is the key to solve the problem. It is obvious that the influencing factors of doctor moral hazard objectively exist in the perspective of economic analysis, and they continued to be studied from the doctors' perspective.

Doctors could take advantage of information asymmetry, which allows them to adjust their specific moral hazard behavior in different contexts of policy. The influencing factors of doctor moral hazard are also ever-changing. Grounded theory is a method of qualitative research proposed by Glaser and Strauss (1967), which possesses the simplicity of traditional quantitative research and overcomes the limitations of traditional qualitative research. Our study aims to conduct a qualitative study on the influencing factors of doctor moral hazard based on the methods and techniques of grounded theory to figure out a more effective method for the prevention and control of doctor moral hazard in the process of medical reform (Einav et al., 2013; Harper, 1987).

Our article describes and defines the internal structures of doctor moral hazard by using grounded theory and qualitative research methods to create semi-structural questionnaires to guide in-depth interviews for classical samples. Therefore, studies on the factors that lead to doctor moral hazard are essential to better understand its mechanisms and corresponding preventive measures.

\section{Methods}

The process of grounded theory can be divided into nine steps and five phases: review and discussion of relevant literature; case selection; development of strict data collection protocol; data collection; data ordering; data analysis of the first case; theoretical sampling; reaching closure; and comparison between the new and the existing theories (Pandit, 1996).

We used theoretical sampling as the basis of data collection. Theoretical sampling depended on the research goal and was part of grounded theory. Initially, a few sample cases were selected and explored in depth. The samples were considered data sources with broad representativeness, which distinguished this sampling from the large-scale random sampling commonly used in quantitative studies (Handberg; Thorne, 2015). The grounded theory intrinsically requires that the theoretical samples must be representative in breadth and depth, and the researched objectives may be changed dynamically according to the sample data until data decoding reaches some degree of saturation (Vedana et al., 2017). The research process of grounded theory is shown in Figure 1.

\section{Figure I - The process of grounded theoretical research}

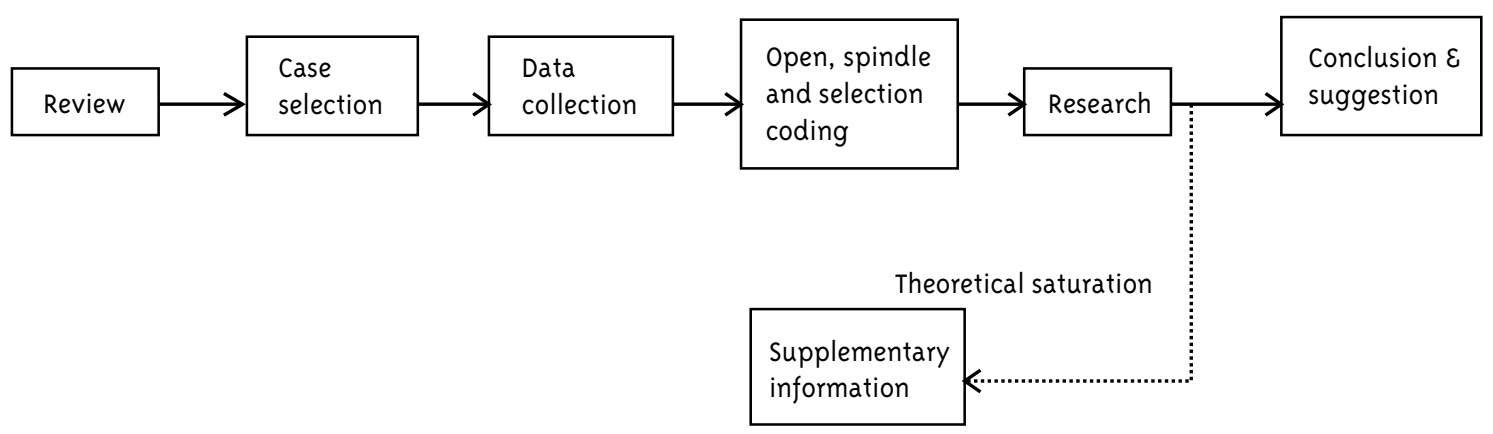


There are different conceptions of doctor moral hazard involving patients, nurses, doctors, and hospital managers. They included both young doctors and retired experienced doctors, from either small or large hospitals that offered different services. We selected ranges of interviewees from these categories. To avoid the subjective biases and compromised responding from the interviewees as much as possible, data was collected by adopting a semi-structured method. According to the grounded theory, by comprehensive sampling (collecting, analyzing and sampling synchronously) and continuous comparison, the number of samples was determined according to the maximum difference information saturation to achieve information saturation. We conducted in-depth interviews with 24 individuals from October 2019 to December 2019. Table 1 shows interviewees' characteristics.

\section{Table I-Characteristics of interviewees}

\begin{tabular}{|c|c|c|c|}
\hline & Category & Number & Percentage \% \\
\hline \multirow[t]{2}{*}{ Gender } & Male & 13 & 54.2 \\
\hline & Female & II & 45.8 \\
\hline \multirow[t]{4}{*}{ Age } & "25 years old & 6 & 25 \\
\hline & $26-35$ years old & 8 & $33 \cdot 3$ \\
\hline & $36-45$ years old & 6 & 25 \\
\hline & $" 46$ years old & 4 & 16.7 \\
\hline \multirow[t]{4}{*}{$\begin{array}{l}\text { Educational } \\
\text { background }\end{array}$} & Doctor & 2 & 8.3 \\
\hline & Postgraduate & 6 & 25 \\
\hline & Graduate & II & 45.8 \\
\hline & Others & 5 & 20.9 \\
\hline \multirow[t]{3}{*}{$\begin{array}{l}\text { Hospital } \\
\text { grade }\end{array}$} & First-class & 12 & 50 \\
\hline & Second-class & 5 & 20.8 \\
\hline & Third-class & 7 & 29.2 \\
\hline \multirow[t]{3}{*}{ Position } & Doctor & 12 & 50 \\
\hline & $\begin{array}{l}\text { Management } \\
\text { personnel in } \\
\text { hospitals }\end{array}$ & 6 & 25 \\
\hline & Nurse & 6 & 25 \\
\hline
\end{tabular}

Three days before the interview, we contacted the interviewees by telephone, email, WeChat - a mobile instant text and voice messaging communication service that has become an important social media platform in China (Lien; Cao, 2014) -, doorto-door visit, and other means to inform them of the purpose, format and topic of the interview. Moreover, we conducted preliminary contact between the researchers and the interviewees to eliminate possible communication obstacles. The interviewees were requested to talk briefly about and reflect on their own work or patient experience and prepared for the interviews. The effectiveness of the formal interview can be ensured by the preliminary preparation and confirmation of the time and place can ensure the conduction of the plan of formal interviews.

During the formal interviews, the researcher explained the concept and the influencing factors of doctor moral hazard before conducting in-depth interviews. Since doctor moral hazard is a sensitive issue among doctors, we used a question-changing technique in the interview so as to ensure that doctors could discuss the issue frankly and honestly and not intentionally conceal relevant information. We collected indirectly the information we needed by presenting opinions from other hospitals and other medical practitioners about the factors that influence doctor moral hazard (Debpuur, 2015; Mendoza, 2016). The main interview questions were as follows:

1. What do you know about the factors that lead to doctor moral hazard?

2. How do you classify the factors that lead to doctor moral hazard?

3. Which inducing factor do you think is the most important?

4. What do you think about the internal regularity of these inducing factors?

5. Do you think these factors can be reclassified?

During the interview, we asked the interviewees to elaborate or explain their answers and some key points.

We adopted a face-to-face approach in the in-depth interviews, intending to gain the trust of the interviewees and thereby encouraging 
the interviewees to express their thoughts. We also recorded the interviews to observe the facial expressions and body language of the interviewees to have an insight into their psychology. The interview lasted for at least one hour to ensure quality. The interviews ended when no new information was given by any of the interviewees (the three elements of new information: not included in the knowledge summary, given by the interviewees, and valuable for the study topic). After each interview, the researchers reflected on the content and summarized the interview to determine the direction of the next sample and recorded their observations and conclusions.

\section{Findings}

\section{Open coding}

Data gathered in the study were encoded using the qualitative data analysis tool NVivo11, which has considerable functionality to help researchers systematically collate and analyze unstructured data. Encoding is part of grounded theory methodology. With the aid of the software, 24 cases of respondents and 185 reference points were coded. After deletion and merging, 134 initial concepts were obtained, and 19 categories (a1-a19) were obtained after induction and sorting (Table 2). Five main categories (A1-A5) were further obtained by selective coding (Table 3 ). We discussed with experts about the theories and practice during the coding process to avoid subjective bias and predetermined conclusions.

\section{Selective coding}

We reviewed and scrutinized each category, and based on medical practice, we extracted five main categories (motivation, opportunity, self-rationalization, exposure and punishment). The interviewed medical staff believed that no matter what the macro and institutional reasons, they ultimately played a role by influencing the aforementioned five aspects of individual doctors. We analyzed the influencing factors of all five major categories, as shown in Table 3.

\section{Table 2 - Concepts and categories derived by open coding}

\begin{tabular}{|c|c|c|c|}
\hline Number & Categories & Concepts & Frequency \\
\hline al & $\begin{array}{l}\text { Economic } \\
\text { demand }\end{array}$ & $\begin{array}{l}\text { Hospitals actually have requirements for doctors' performance. The third } \\
\text { invisible hand inspires doctors. Doctors' work too hard and many doctors } \\
\text { need more financial compensation. }\end{array}$ & 55 \\
\hline a2 & $\begin{array}{l}\text { Technological } \\
\text { demand }\end{array}$ & $\begin{array}{l}\text { New technology requires doctors to have plenty of training opportunities. } \\
\text { Doctors need one or two unique skills in technology to possess discourse power } \\
\text { in the field. Hospitals have incentive mechanisms for new technologies. }\end{array}$ & 34 \\
\hline a3 & $\begin{array}{l}\text { Scientific } \\
\text { research } \\
\text { demand }\end{array}$ & $\begin{array}{l}\text { Doctors need clinical records to support their research subjects, so they will make } \\
\text { decisions for the purpose of scientific research. The promotion of doctors must be } \\
\text { based on scientific research performance. Some doctors with an excellent work } \\
\text { are not promoted if they do not have scientific research performance. }\end{array}$ & 24 \\
\hline 24 & $\begin{array}{l}\text { Demand from } \\
\text { patients and } \\
\text { their families }\end{array}$ & $\begin{array}{l}\text { Patients have inclinations for new technologies such as cesarean section, and } \\
\text { doctors abide by the patients' irrational demands. Patients and their families } \\
\text { do not have confidence in conservative treatment, have a limited mental } \\
\text { endurance and operations must be done in advance. }\end{array}$ & 62 \\
\hline a5 & Other demands & $\begin{array}{l}\text { For teaching purposes, doctors deliberately treat patients according to the } \\
\text { plan set instead of the requirements of the illness. } \\
\text { To save time, doctors did not strictly implement the requirements of the } \\
\text { core medical system. }\end{array}$ & 33 \\
\hline
\end{tabular}


Table 2 - Continuation

Opportunity

a6 of medical decisionmaking

Restriction on decision- making

procedures

Patients' role

in decision

making

Behavior that

causes no harm

Behavior independency

Behavior traceability

Spot checks on industry supervision

Spot check on hospital supervision

Spot check on department supervision

Spot check on medical group supervision

Industry penalties

Hospital penalties

Department penalties

Medical group penalties
Doctors have many independent decision-making opportunities. Even if patients take part in the decision-making process, doctors make the final decision. Although doctors have to abide by national laws and regulations, they seem to only represent a formality, thus, in practice, doctor make the decisions.

The hospital fully authorizes doctors to make decisions and the control of the process is only a formality. Moral hazard behavior is not restricted by regulations made by the hospital.

Patients have no ability to participate in medical decision-making; Patient participation in decision-making is a mere formality.

Many moral hazard behaviors are non-invasive and will not cause adverse consequences.

Medical behavior is difficult to be defined individually, and many behaviors are intertwined and equivocal, including patients' individual factors.

The frequency and intensity of spot checks on industry supervision, and the probability that the doctor moral hazard behavior will be discovered.

The frequency and intensity of spot checks on hospital supervision and the probability that the doctor moral hazard behavior will be discovered.

The frequency and intensity of spot checks on department supervision, and the probability that the doctor moral hazard behavior will be discovered. moral hazard behaviors are threatened with punishment by the departments. 
Table 3-Main categories of open coding

\begin{tabular}{|c|c|c|c|c|}
\hline Number & Main categories & Categories & Frequency & Percentage/\% \\
\hline Al & motivation & $\begin{array}{l}\text { al Economic demand a2 Technological demand } \\
\text { a3 Scientific research demand a4 Pressure from } \\
\text { patients and their families as Other demands }\end{array}$ & 24 & 17.8 \\
\hline $\mathrm{A} 2$ & Opportunity & $\begin{array}{l}\text { a6 Medical decision-making opportunity a } 7 \\
\text { Restriction on decision procedures a8 Patients' role } \\
\text { in decision making }\end{array}$ & 22 & 16.6 \\
\hline $\mathrm{A}_{3}$ & self-rationalization & $\begin{array}{l}\text { ag Behavior traceability } \\
\text { level aıo Behavior independency aı Behavior that } \\
\text { cause no harm }\end{array}$ & 18 & 14.2 \\
\hline $\mathrm{A}_{4}$ & exposure & $\begin{array}{l}\text { a/2 Spot checks on industry supervision al3 Spot } \\
\text { checks on hospital supervision al4 Spot checks on } \\
\text { department supervision al5 Spot checks on medical } \\
\text { group supervision }\end{array}$ & 27 & 18.9 \\
\hline $\mathrm{A}_{5}$ & punishment & $\begin{array}{l}\text { a.6 Industry penalties aı Hospital penalties aı } 8 \\
\text { Department penalties al9 Medical group penalties }\end{array}$ & 17 & 13.8 \\
\hline
\end{tabular}

\section{Selective coding and model building}

According to spindle-type coding, we further analyzed the factors that induce doctor moral hazard. Based on economic theory, due to the objective existence of information asymmetry and the externality of medical practice (the existence of the second profession of doctors), there must exist doctor moral hazard in medical decision-making. Despite the complicated variety of influencing factors, which can still have certain rules and can be recognized. According to interviews, selective coding was used to construct a model of the factors that lead to doctor moral hazard, which was combined with relevant theories and practice, as shown in Figure 2. The model was constructed based on spindle-type coding, in which demand was the motivating factor that induces doctor moral hazard and caused all related behaviors. Practical needs from doctors are the premise and foundation of all of their moral hazard behavior. Opportunity is the factor behind doctors' moral hazard; without the opportunity, doctor moral hazard behavior cannot happen. It is precisely the opportunity that allows doctors to make direct decisions or guide decisions in medical services, which results in moral hazard behavior. Self-rationalization further aggravates the occurrence of doctor moral hazard and becomes a contributing factor. Because of mental idiosyncrasies or their own rationalizations, doctors suppress their sense of moral shame. Exposure level increases doctor moral hazard. When doctors think their own moral hazard behavior is not likely to be discovered, they will display out more moral hazard behavior. On the other hand, when doctors think their own moral hazard behavior are more likely to be discovered, they will reduce that behavior. Finally, the threat of punishment is always eminent. However, if the threat of punishment is low, moral hazard will be hardly controlled. On the other hand, if the threat of punishment is high, doctors have to abandon the opportunity to display a moral hazard behavior. 
Figure 2 - The factors that lead to doctors' moral hazard

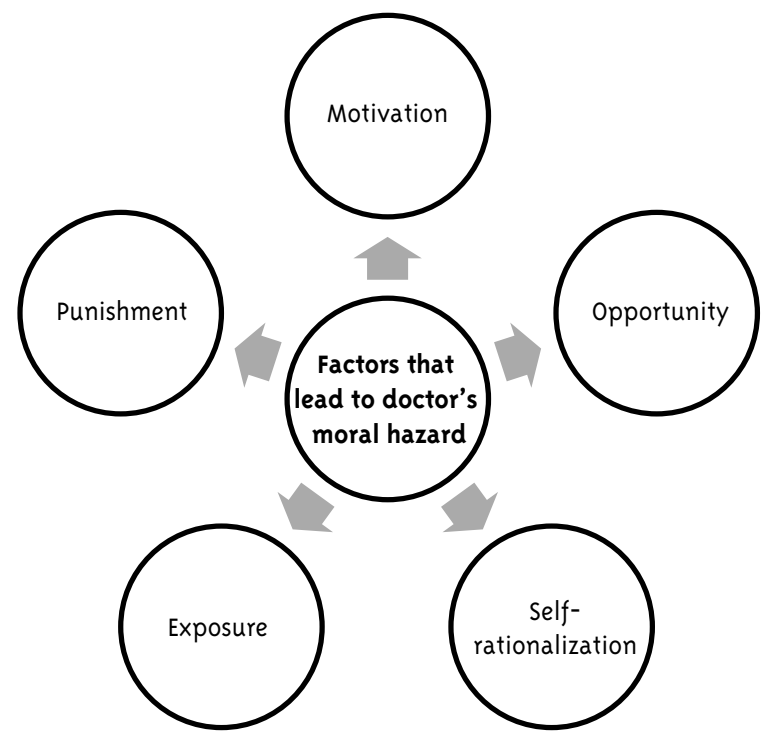

\section{Discussion}

\section{Motivation}

Such behaviors are influenced by certain motivations. Motivation comes from the need or pressure either in daily life or in medical activity of doctors. Doctors' diverse practical needs constitute the premise and foundation of all their moral hazard behavior. The pressures that lead to doctor moral hazard include economic pressure, promotion pressure and external pressure. Economic pressure refers to the income requirement to perform certain medical services based on the performance requirements of hospitals or departments; this requirement is the basis on which doctors earn salaries and bonuses in their hospitals. On the other hand, doctors are pressured to obtain more income for individual reasons due to their lifestyle or economic needs (Lundin, 200o).

Promotion pressure: as members of the medical system, doctors are generally confronted with promotion pressure in the field. First, there is the pressure regarding scientific research: to complete scientific research tasks, doctors generally need to conduct case studies that meet the requirements of scientific research; the second is technical pressure, especially the use of new and high technology. Doctors need to perform all types of difficult operations to indicate their influence and position in the field. These pressures from scientific research and technology often encourage doctors to take more risks or make more medical attempts than necessary.

External pressure: doctors are also subject to many external pressures, the most important of which is the pressure of various commercial offerings that are popularized by suppliers (Einav et al., 2013). That is, there are countless invisible hands behind doctors that induce to display a moral hazard behavior. Moreover, pressure from doctorpatient conflicts, social media and other aspects, including doctors' own high-intensity work pressure, urges doctors to preserve their sanity and keep their treatment behaviors conservative in many cases.

It is within such a complicated environment that doctors are stimulated to display, for their own benefit, opportunistic behaviors that may be unfavorable or even harmful to patients.

\section{Opportunity}

Opportunity is the factor behind doctor moral hazard, without which moral hazard behaviors cannot be shown. Based information asymmetry, the role of medical decision-making and guidance in the process of disease treatment is particularly important. Even if some patients need to participate in the decision-making process, doctors' thoughts and opinions often dominate the final decision. That is to say, doctors actually exercise their medical decision-making rights, which they should, since the law stipulates and authorizes the doctors' unilateral rights in case of emergency. Due to the current situation of information asymmetry and the limited engagement of patients in medical services, patients often can only choose a fully qualified doctor. Due to the professionalism of medical knowledge and technology, there is an obvious information asymmetry between doctors and patients. When treating the patients' diseases, there may be many questions: what examination 
should be undergone? What drugs should be administered? Is all surgery needed? Doctors have absolute informational advantages regarding specific surgical methods and related medical treatments, such as the choice of materials needed for surgery. However, if doctors did not have decision-making rights, their moral hazard would be limited to a certain range even if they possess informational advantage (Chetty, 20o8).

\section{Self-rationalization}

The high level of self-rationalization has further intensified doctor moral hazard behavior. The moral shame of doctors is suppressed either by mental idiosyncrasies or by individual rationalizations. Since the treatment of diseases is a process of analyzing multiple causes and effects, there is treatment uncertainty in medical services. Therefore, it is difficult to accurately evaluate or define whether treatment measures are effective. During this process, doctors can easily present their equivocal behavior in medical services as behavior worth trying and without risks. That is, due to the uncertainty of medical results, it is difficult to trace a certain speculative behavior regarding the investigation its results and doctors' corresponding responsibilities. Doctors also exhibit moral disengagement related to medical accidents and complications. In the process of diagnosis and treatment, even if there are errors or irregular behaviors, doctors often argue that these behaviors have nothing to do with the consequences of their decisions, instead insisting that these results are medical accidents or complications within the normal range.

\section{Exposure}

The exposure degree of doctor moral hazard behavior directly affects whether doctors implement speculative behavior in the process of decisionmaking. When doctors think the probability of their moral hazard behavior being discovered is low, they will enlarge their moral hazard behavior. Otherwise, they will reduce or even give up their moral hazard behavior. From this point of view, the degree of exposure is the regulator of doctor moral hazard. In the interview, it is interesting to find that once a certain kind of medical behavior is often inspected, it will significantly reduce or even eliminate corresponding doctor moral hazard behavior, since being inspected means increasing the possibility of being discovered.

\section{Punishment}

Finally, the threat of punishment are always eminent. If the threat of punishment is low, it will be difficult to control moral hazard. Otherwise, the doctor will have no choice but to give up the opportunity to display a moral hazard behavior, because they will identify and assess the possible consequences of their moral hazard behavior and adjust those behaviors according to the results of their assessment. In the interview, many hospital managers believed that the current punishment to medical behaviors is not severe enough, the timeliness of punishment is not fast enough, and the scope of punishment is not wide and deep enough, which directly affects the occurrence and existence of moral hazard behavior. On the other hand, in a context of more severe punishment, the incidence of doctor moral hazard behavior is relatively low. Compared with the punishment of hospitals and medical groups, industry punishment and department punishment are more severe. Department punishment refers to the administrative punishment to the doctors that have moral hazard behavior by the government regulatory departments corresponding to various relevant businesses of the hospital, such as medical treatment, drugs, consumables, etc.

\section{Final remarks}

In our study, selective coding was performed based on spindle-type coding, and a model of the factors inducing doctor moral hazard has been constructed. The motivation was the motive force behind the factors that induce doctor moral hazard and cause all related behaviors. Doctors' practical needs constitute the premise and foundation of all doctor moral hazard behavior. The opportunity is 
the factor underlying doctor moral hazard. Without the opportunity, doctor moral hazard behavior cannot be displayed. Self-rationalization, in turn, has further intensified the occurrence and existence of doctor moral hazard. Doctors' moral shame is suppressed either by mental idiosyncrasies or by individual rationalizations. Low degree of the exposure of doctor moral hazard behavior is an amplifier of doctor moral hazard. When doctors think their own moral hazard behaviors have a low probability of being discovered, they will increase their moral hazard behaviors. Otherwise, they will reduce their moral hazard behaviors. Finally, the threat of punishment are always eminent. If the threat of punishment is low, controlling doctor moral hazard is difficult. Otherwise, doctors just have to give up the opportunity to display a moral hazard behavior. Regarding the theoretical model of the factors inducing doctor moral hazard, further empirical research is required to explore and elaborate the mechanism. However, according to the framework model of influencing factors of doctor moral hazard obtained in our study, the corresponding prevention and control system of doctor moral hazard can be established. The corresponding prevention and control strategies can be formulated for specific types of influencing factors. Regarding motivation, reasonable regulation and control are demanded, especially to strengthen the prevention of personal irrational motivation of doctors; regarding opportunities, the design of processes and systems should be adopted to reduce the opportunities for doctors to have too many autonomous rights; regarding self-rationalization, it is necessary to strengthen the professional education of doctors to enhance their inner self-consciousness to resist moral hazard; in the exposure dimension, improving the openness and transparency of medical behaviors and increasing the possibility of moral hazard exposure by combining with various examinations is essential; concerning punishment, it is paramount to increase the intensity of punishment for moral hazard behaviors, and ensure the rigidity of implementation, so as to gradually form a good atmosphere of doctors' self-restraint.

\section{References}

ARROW, K. Uncertainty and the welfare economics of medical care. American Economic Review, Ann Arbor, v. 53, n. 5, p. 941-973, 1963.

CHETTY, R. Moral hazard versus liquidity and optimal unemployment insurance. Journal of Political Economy, Chicago, v. 116, n. 2, p. 173-234, 2008.

CHERAGHI, R. et al. The study of induced demand done CT scan services in Imam Reza Hospital 2015. Revista Publicando, San Juan, v. 5, n. 16. p. 427-434, 2018.

DEBPUUR, C. et al. An exploration of moral hazard behaviors under the national health insurance scheme in Northern Ghana: a qualitative study. BMC Health Services Research, California, v. 15, art. 469, 2015.

DORAN, E.; ROBERTSON, J.; HENRY, D. Moral hazard and prescription medicine use in Australia: the patient perspective. Social Science \& Medicine, Amsterdam, v. 6o, n. 2005, p. 1437-1443, 2004.

EINAV, L.; FINKELSTEIN, A. Moral hazard in health insurance: what we know and how we know it. Journal of the European Economic Association, Hoboken, v. 16, n. 4, p. 957-982, 2018.

EINAV, L. et al. Selection on moral hazard in health insurance and self-protection. American Economic Review, Nashville, v. 103, n. 1, p. 178-219, 2013.

ELIASON, M.; JOHANSSON, P.; NILSSON, M. Forward-looking moral hazard in social insurance: evidence from a natural experiment. Uppsala: Institute for Evaluation of Labour Market and Education Policy, 2018. (Working Paper, n. 11).

EVANS, R. G. Supplier induced demand: some empirical evidence and implications. In: HICKS, L. Economics of health and medical care. New York: Macmillan, 1974. p. 162-173.

HANDBERG, C.; THORNE, S. Revisiting symbolic interactionism as a theoretical framework beyond the grounded theory tradition. 
Qualitative Health Research, Thousand Oaks, v. 25, n. 8, p. 1023-1032, 2015.

HARPER, D. Qualitative analysis for social scientists. Contemporary Sociology, Thousand Oaks, v. 3, n. 5, p. 16-19, 1987.

GLASER, B. G.; STRAUSS, A. The discovery of grounded theory: strategies for qualitative research. Chicago: Aldine,1967.

LEVIT, K. et al. Health spending in 1998: signals of change. Health Affairs, Bethesda, v. 19, n. 1, p. 124-132, 2000.

LIEN, C. H.; CAO, Y. Examining WeChat users' motivations, trust, attitudes, and positive word-ofmouth: evidence from China. Computers in Human Behavior, Amsterdam, v. 41, p. 104-111, 2014.
LUNDIN, D. Moral hazard in physician prescription behavior. Journal of Health Economics, Amsterdam, v. 19, n. 5, p. 639-662, 2000.

MENDOZA, R. L. Which moral hazard? Health care reform under the Affordable Care Act of 2010.

Journal of Health Organization and Management, Bingley, v. 30 n. 4, p. 510-529, 2016.

PANDIT, N. R. The creation of theory: a recent application of the grounded theory method. The Qualitative Report, Fort Lauderdale, v. 2, n. 4, p. 1-13, 1996.

VEDANA, K. G. G. et al. Emergency nursing experiences in assisting people with suicidal behavior: a grounded theory study. Archives of Psychiatric Nursing, Bethesda, v. 4, n. 31, p. 345-351, 2017.

\section{Acknowledgement}

This study was supported by the Major Program of Philosophy and Social Science Research in Jiangsu University (Grant no. 2020SIZDA085).

\section{Authors' contribution}

Yaohui Wang and Quanlong Liu set the theme, outlined the research, and performed the article critical review. Xifeng Wang and Jiankun Dong reviewed the data collection instrument, coordinated data collection, elaborated the statistical analyses, and reviewed all sections of the article. Xinchun Li developed the data collection instrument and the discussion, formatted the references, and revised the final version of the manuscript, which was approved by all authors.

Received: 08/23/2020

Approved: 09/09/2020 